\title{
Aesthetic Values in Balada Cenderawasih Traditional Dance of Papua
}

\author{
$1^{\text {st }}$ Sri Winarsih* \\ Department of English Literature \\ Universitas Musamus \\ Merauke, Indonesia \\ sriwinarsih@unmus.ac.id
}

\author{
$2^{\text {st }}$ Margaretha Febriany Narahawarin \\ Department of English Literature \\ Universitas Musamus \\ Merauke, Indonesia \\ narahawarin_fkip@unmus.ac.id
}

\author{
$3^{\text {st }}$ Natalia Manuhutu \\ Department of English Literature \\ Universitas Musamus \\ Merauke, Indonesia \\ manuhutu_fkip@unmus.ac.id
}

\begin{abstract}
This study aims to find out the aesthetic values in Balada Cenderawasih, a traditional dance of Papua. Balada Cenderawasih is a traditional Papuan ballad performed in the dance moves. The contents of literary and artistic are fully included in it which can be explored more than just a performance on the stage. One of several ways to explore is by finding out the aesthetic values through a study. This study is descriptive qualitative with the source data obtained from the dance move sequences, informant, and the synopsis. The data were collected by overt observation, structured interview, and documentation, then were analyzed using Miles and Huberman's three steps; reduction, display, and verification. The results of the study show that the aesthetic values are found out based on the 3 aesthetic elements; appearance, substance, and presentation. 1) Appearance; a) Form: the formation of a group of birds symbolizing beauty, binary opposition and leadership, b) Structure: the unity, the dominance, and the balance symbolizing the structure of leadership; 2) Substance; a) Tone; mode change leading to raising emotion, b) Idea; showing chronological journey, c) Message; reminding people of environmental endangerment; 3) Presentation; Three elements of unity, complexity, and intensity presenting the quality of the dance performance which determining the whole elements of aesthetic values.
\end{abstract} dance

Keywords: aesthetic value, balada cenderawasih, traditional

\section{INTRODUCTION}

Literary work reflects part of life as an example of the messages wished by the author to deliver through his work as Afrinda [1] stated that literary work deals with society, reality, and the truth. It has three kinds; poetry, prose and drama. One of kinds of poetry is ballad. Ballad is a poem contains story of divine beings or superpower characters. It is in the form of narrative telling a chronological story as defined by Waluyo [2]. While Rafiq [3] has explained the definition of ballad as, "a poem meant for singing, quite impersonal in material, probably connected in its origins with the communal dance but submitted to a process of oral traditions among people who are free from literary influences and fairly homogeneous in character." In short, ballad is presented with music and narrative.

One famous ballad known by people in Papua is called Balada Cenderawasih. It is the traditional dance of Papua which is often performed in some important events in Papua such as anniversary of Papua province, anniversary of regencies, and some other events. Once, the local government of Jayapura set a group of students to perform this dance at National Education day celebration after the ceremony [4]. The dance was performed with the purpose to remind audiences to keep and maintain the environment including the Paradise Birds.

In general, the dance tells about a group of birds and a hunter with lyrical poem and music. Cenderawasih is a kind of birds called Paradise bird in English. For Merauke people, the bird is the natural wealth of Merauke which is the ecosystem is abundant in Wasur National Park of Merauke, as a study held by Yekbat \& Maturbongs [5]. Based on the definition of ballad, Balada Cenderawasih has the characteristics of ballad. It is lyrical poem meant for singing, it is connected with the communal dance but submitted to a process of oral tradition among people. It means that Balada Cenderawasih has literary and artistic contents. Literary content derives from the oral tradition and the poem, while artistic content derives from the dance. Both of them are packed in a performance. Performance is enjoyed by sights of the audiences which must present the beauty to satisfy the audiences.

Triki [6] said that the idea of beauty, psychological experience requiring feeling of pleasure refers to aesthetic experience. While Djelantik [7] stated that aesthetics is knowledge learning about everything related to beauty, and learning all aspects of what is called beauty. In addition, Zaenuri \& Lestari [8] extended that "Aesthetic does not only present beauty that gives pleasure without any interest of the sense, but also gives a recognition for people in terms of developing social, economic, politic, and culture phenomenon". It means that aesthetics is more than beauty captured by eye sights or pleasure of feeling but dealing with particular values.

Regarding with aesthetics, Djelantik [7] categorized aesthetics into some elements namely 1) Appearance, it deals with form and structure; 2) Substance, it deals with tone, idea, and message; 3) Presentation, it deals with unity, complexity, and intensity. All of those elements are potentially able to dig out the aesthetic values more than captured by eye sights but refers to all aspects of the literary and artistic contents in a performance. 
Based on the exposure above, studying about Balada Cenderawasih viewed from the elements of aesthetics [7] can be one of advantageous study since it aims to find out the aesthetic values contains in all aspects of the performance. It helps people to enjoy the performance not only by eye sights but also by pleasure of feeling because they find the values behind the moves in the dance. It also will bring people either to enjoy the performance or to appreciate it more than just a performance but the values since Balada Cenderawasih originally comes from oral tradition which means fully contains with value of culture and society. In addition, the result of the study can be one of the references for further studies in the field of developing literature based- learning materials as mentioned in the devotion activity by Narahawarin \& Winarsih [9].

\section{RESEARCH METHODS}

This is descriptive qualitative study with the object of study is in the natural setting in which Balada Cenderawasih was performed as usual on the stage without any interference from the outsiders, so it is also called naturalistic study as Prastowo [10]. The descriptive data were collected from the dance move sequences through overt observation, from the informant through structured interview, and the synopsis through documentation. The all of the data collected were analyzed using three steps of Miles and Huberman; reduction, display, verification. to validating the data, the researchers applied triangulation technique of the three steps as explained in Sugiyono [11].

The Balada Cenderawasih studied by the researchers was performed in about 16 minutes by the dancers and managed by Dahuke'he studio Merauke Papua located on Jl. Garuda Spadem. The informant of the source data is the head of Dahuke'he studio and the synopsis of the ballad is originally Balada Cenderawasih of Dahuke'he version.

\section{RESULTS AND DISCUSSION}

The aesthetic values can be drawn by the elements of aesthetics categorized by 1) Appearance, 2) Substance, and 3) Presentation [7];

\section{A. Appearance}

Appearance as the elements of aesthetics is divided into 2 points; Form and Structure. It views the aesthetic from the eye sight but digs out the values from the symbols alerted.

\section{1) Form}

Form is what is appeared in concrete or abstract. Concrete means it is seen and heard. While abstract is seen by imagination. Form is created by dot, line, stretch, space, color.

Dot in the dance is an abstract. A dot can be meant as the dancer individually. In the synopsis, it is drawn many dots in every scene of the sequences which the dots are made as telling the position of the dancers. From a dot becomes many dots shows the beauty of choreography or formation of group dance. In addition, the dancer represents a Paradise bird. It portrays the life of the bird which sometimes plays individual role and sometimes involves into a group of birds. The aesthetic values appear in that truth that the portrait of human life is brought into a formation of a group of birds.

As the dot, line in Balada Cenderawasih is also an abstract but it is clearly showing by the position of the dancers. The role of the dancers shows two positions, the first as birds in couple, and birds as a group. Birds in couple can be symbolized by the line of horizontal which can be meant as binary opposition of male and female, while the vertical one can be meant as binary opposition of the leader of the group of birds to his member. The concept of binary opposition as Saussure's Theory [12] that the binary opposition is about the relationship of things, but it is not about the contradictory relation but a structural, complementary one. It can be underlined as the aesthetic values which is drawn by line symbolizing the relationship between the dancers.

Beside dot and line, stretch in the dance patterns represents the moves of the dance which are divided into several scenes. Every piece of the scenes depicts important chronological moves for the dancers and the audiences. The dancers should remember every piece of their part, while the audiences will watch and feel in every part. The chronological scene will be discussed in the next subheading because it is related to the part of substance.

In addition, the space in the dance formation implicitly represents the setting of the dance. As mentioned before that ballad is a poem contains of narrative story, therefore there always be the setting. Only by eye sight, the audiences directly know that the setting of the story in the ballad is in the forest where the birds are living freely. It is indicated by the moves where the birds are flying and then perching on a tree before the hunter is coming closely.

The color of the dancers' costume is dominant with brown and yellow with the little combination of rainbow colors, especially the wings and the head accessories. The color clearly identically refers to Paradise birds. In fact, the beautiful color of the birds precisely brings them into endangerment because most of wild hunters are eyeing on them. That condition is the depiction of an irony. Beygi \& Bheman [13] mentioned the concept of irony that it conveys the opposite condition of what it said. In real life people wish to have beautiful look and appearance but then ironically, the condition brings them into the risk of endangerment.

Based on the appearance, the aesthetic values of Balada Cenderawasih show in the dancers as individual figure, and the member of group formation of Paradise birds which have beautiful colors. They show the symbol of binary opposition between male and female, and also between leader and the member. In addition, they also represent the ironical condition that sometimes happen in life cycle in real life which is drawn from the opening as life is just started and then the closing as the story ended.

\section{2) Structure}

Structure refers to how the whole basic elements of the dance created until becomes a performance on the stage. It is divided into three points; Unity, Dominance, Balance.

Unity is formed by the sequences of the dance moves and the togetherness of the dancers in playing their own parts. The structure of unity in the dance shows the structure of a leadership since it is ruled by the leader and followed by the members.

Dominance is positively means attracting audiences' attention to the important parts of the dance. So, the dominance is in the dancer who plays as the leader of the 
birds. He wears different costume and attributes, he enters the first and he is the one who involves in the climax plot that is killed by the hunter. The leader of the birds, if it puts in the characteristics of the narrative, he must be the main character of the story.

Balance, the dominance of the leader does not mean that the other dancers do not play the important role. The role of the dancers as the members builds the balance in the formation of the dance. As if in the leadership formation, the leader leads his member and the members obey their leader. It cannot be happen if one of them is in absence. They are like a construction which is tied one another.

Based on the structure of the dance, it depicts the structure of leadership formation. The aesthetic values appear in the fact that a group dance formation depicts the structure of plot of a narrative and such a structure of leadership.

\section{B. Substance}

Substance of literary and artistic contents is not only seen by eye sight but also felt by its meaning and value. There are three elements of substance; tone, idea, and message.

\section{1) Tone}

Tone is the environment built in the dance. It is sometimes strongly influenced by the music or instrument. In Balada Cenderawasih, the tone experiences the mode change from the happiness to sadness. The dance begins with rapid beat of wasp of Tifa (Papuan traditional musical instrument) which gives taste of happiness. But then it happens in the scene of the leader bird is killed by the hunter, the musical instrument turns into slow beat and the mourning of the singer's voice. The mode change must success in giving surprise and raising emotion of the audiences.

2) Idea

Idea of Balada Cenderawasih is clearly as the characteristics of lyrical poem which tells narrative and accompanied by music. Sauhenda et. al. [14] defined narrative text is a type of explanation of a process. The sequences of the scenes completely follows the structure plot of narrative While Tjahyono [15] and Mido [16] stated that plot can be divided by some elements; (1) introduction; it shows from the entrance by the snooper bird which is checking the situation for them to fly around and then followed by the cheerful birds in group dancing and singing as the symbol that they are happy together, (2) complication; it starts when the hunter suddenly appears and eyes on the most beautiful bird, that is the leader bird, (3) Climax; it happens when suddenly the leader is shot by the hunter using arrows, (4) Denouement; it presents the scene when the birds are crying and the hunter is regret by breaking off his arrows and hold the dead bird into his arm, and (5) Resolution; it ends sadly when the birds move and leave the forest.

\section{3) Message}

The literature represents the reality of life [1] while the art is the tool to deliver it. The message is the main point of the performance that can be brought by the audience until home. The message of Balada Cenderawasih is reminding people of the endangerment of the environment especially in fauna extinction by the wild hunter. A case study conducted by Yebat \& Maturbongs [5] revealed that there are still many illegal trades in wildlife including Paradise birds. By the fact, Balada Cenderawasih is often performed in important occasions to the demo of protected animals such as Paradise birds. In the Balada Cenderawasih dance moves, there is a move that is called Gatsi. Marnina in her study [17] described Gatsi as a traditional dance from Marind tribes who describe that Marinds always submitted to their culture even the age become modern.

\section{Presentation}

Presentation of Balada Cenderawasih basically refers to the whole package of the performance on the stage. It begins from the dancers, the choreography, the music, the costumes, the lighting, the timing and the story of ballad itself. Those packages are used to attract interest of the audiences. Bawawa [18] convinced that the good visual can attract more interest. The visual can be divided into unity, complexity, and intensity.

\section{1) Unity}

The unity has been discussed in the subheading previously. But in this point, the unity means the whole package mentioned above. Balada Cenderawasih presents the unity of a dancer group or unity of teamwork. But if it is related to the life of the birds it shows the unity of group of birds.

\section{2) Complexit}

The complexity shows the rich materials of the dance. It is not the simple dance but well prepared from the beginning in all aspects. The dancers play different roles, the costumes are well matched with their roles, the music is suitably accompanied as its' mode.

\section{3) Intensity}

The intensity of Balada Cenderawasih comes from the plot structure which can tell crucial message to the audience. Intensity refers to the dance moves that are full of message even from the first scene to the last.

Those three elements above, the unity, complexity, and intensity give the audiences more than a performance. They present the literary and artistic which contain cultural and social issues.

\section{CONCLUSION}

Balada Cenderawasih is one of famous traditional Papuan Ballad which fully contains literary and artistic contents. One of several ways to enjoy a performance is more than just by eye sight but trough studying what messages or values hidden behind it. One of important values to dig out from a performance is aesthetic values. Aesthetic values refer to the beauty of the whole aspect of the performance. It's not only the beauty what captured by eyes but the beauty which is related to the social, economic, politic, and culture as happened in real life.

Therefore, the aesthetic values in Balada Cenderawasih are found out based on the elements of aesthetics. The first, appearance shows the way of life of bird which live individually or in group. in this case, the bird is Paradise birds which is special protected bird by government. It also represents that the structure of life basically as archetypal pattern that is by leadership in which one as the leader and others are the member. The second, the substance shows that the idea of the ballad that is the narrative genre with the complete plot structure. It is started from the happy mode then suddenly changes into the sad one which can raise audience emotion and gives important message of environmental awareness especially the fauna extinction. The 
last, the presentation of Balada Cenderawasih shows perfect unity, complexity and intensity. The unity is presented by the whole package from the dance formation, the costume, the moves, and the music which give pleasure to the audience. Then the complexity and intensity are presented by the plot structure and the materials of the dance moves.

\section{ACKNOWLEDGMENT}

This study was conducted and finished by the support of Rector of Musamus University and the Dean of Faculty of Teacher Training and Education of Musamus University, so the researchers convey gratitude for them for the support both material and spiritual.

\section{REFERENCES}

[1] P. D. Afrinda, "Turn Taking Strategy to Maintain Women 's Self Image in Peri Kopi Novel Written by Yetti A . K . A," Adv. Soc. Sci. Educ. Humanit. Res., vol. 148, no. Icla 2017, pp. 169-174, 2018.

[2] H. J. Waluyo, Pengkajian Cerita Fiksi. Surakarta: Sebelas Maret University Press, 1994.

[3] M. Rafiq, "The Ballad: Definition, Types, and Characteristics," 2017. [Online]. Available: https://owlcation.com/humanities/TheBallad-Definition-Types-Characteristics. [Accessed: 17-Jul2019].

[4] J. Setda Humas, "Tari Balada Cenderawasih Mewarnai Puncak Acara Hardiknas," 2017. [Online]. Available: http://jayapurakota.go.id. [Accessed: 28-May-2018].

[5] M. Yekbat and R. G. Maturbongs, Burung Cenderawasih: Potensi Ekowisata di Selatan Papua. Jayapura: WWF IndonesiaProgram Papua, 2015.

[6] R. Triki, "Aesthetic value, creation and emotion 5th Mediteranian Congress of Aesthetics," in Art, Emotion and value, 2011.

[7] A. A. M. Djelantik, Estetika Sebuah Pengantar. Bandung: MSPI dan Arti, 2004

[8] A. Zaenuri and W. Lestari, "Seni Pembebasan: Estetika Sebagai Media," Harmon. J. Arts Res. Educ., vol. 9, no. 1, pp. 1-12, 2009.

[9] M. F. Narahawarin and S. Winarsih, "Gerakan Literasi Sekolah di SD YPPK Yos Sudarso Kuper Sebagai Upaya Menyukseskan Program Gerakan Literasi Nasional," Musamus J. Lang. Lit., vol. 1, no. 2, pp. 1-10, 2019.

[10] A. Prastowo, Metode Penelitian Kualitatif: dalam Perspektif Rancangan Penelitian. Yogyakarta: Ar-Ruzz Media, 2012.

[11] Sugiyono, Metode Penelitian Pendidikan: Pendekatan Kuantitatif, Kualitatif dan R\&D. Bandung: Alfabeta, 2015.

[12] A. Putri and P. Sarwanto, "Saussurian Binary Opposition as the Narrative Structure of William's Summer and Smoke," J. Lang. Lit., vol. 16, no. 82-98, 2016.

[13] M. H. Beygi and B. Bheman, "To What Extent the Meaning of Different Types of Ironies in King Lear is Translated and Transferred into Persian by Beh Azin (2012) and Peyman (2002)," Theory Pract. Lang. Strudies, vol. 4, no. 6, pp. 1286$1290,2014$.

[14] A. Sauhenda, Marnina, L. Riwu, Z. Santo, and S. Monika, "The Ability to Understand Narrative Text of The Second Semester Students of Indonesian Language and Literature Academic Year 2017/2018 of Musamus University," in Advances in Social Science, Education and Humanities Research, volume 226 1st International Conference on Social Sciences (ICSS 2018), 2018, pp. 1388-1393.

[15] T. Tjahyono, Sastra Indonesia: Pengantar Teori dan Apresiasi. Ende: Nusa Indah, 1988.

[16] F. Mido, Cerita Rekaan dan Seluk Beluknya. Flores: Nusa Indah, 1994.

[17] Marnina, "Used of Person Deixis in Marind Language (A Study of Marind Language in Merauke Papua)," J. Magistra, vol. 4, no. 2, pp. 85-93, 2017.

[18] M. Bawawa, "Using Wall Chart as A Medium for Developing Students Vocabulary Mastery," in Seminar Nasional Kependidikan Inovasi Pendidikan dan Pembelajaran Dalam Rangka Percepatan Pembangunan di Daerah Pinggiran, 2017, pp. 279-284. 